Island Studies Journal, Vol. 9, No. 2, 2014, pp. 259-276 Accidental and ideal island cities: islanding processes and urban design in Belize City and
the urban archipelagos of Europe

\author{
Elizabeth Pigou-Dennis
}

University of Technology, Jamaica

elzbet08@me.com

and

\author{
Adam Grydeh $\phi j$ \\ Island Dynamics \\ Copenhagen, Denmark \\ agrydehoj@islanddynamics.org
}

\begin{abstract}
This paper explores processes of islanding, de-islanding, and re-islanding in the context of island cities. Although today popularly associated with rural, peripheral, and isolated landscapes, concepts of the ideal city coincided in Medieval and Renaissance Europe with emergent notions of the ideal island. Major European cities such as Amsterdam, Paris, and Copenhagen were established on densely urbanized small islands. In accordance with dominant political and military philosophies, they were subsequently developed through comprehensive urban design into vast yet coherent urban archipelagos. In contrast, the contemporary development of Belize City as an island city took place through piecemeal land reclamation, absent comprehensive urban design, resulting in a very different kind of urban archipelago. Neither the coherent European island cities nor Belize City are generally regarded as islands today, yet their histories of urban development evidence the impact of spatial attributes of islandness on urban form. Comprehensive urban design efforts are currently directed at land reclamation and waterfront revitalization in Belize City, aiming to restore Belize City's island city status. We argue that cities can be islanded, de-islanded, and re-islanded in the minds of their inhabitants and that it is necessary to recognize the connection between ideal islands and ideal cities in order to understand the islanding process in full.
\end{abstract}

Keywords: Belize City, ideal cities, land reclamation, island cities, urban archipelagos, urban design.

(C) 2014 - Institute of Island Studies, University of Prince Edward Island, Canada.

\title{
Introduction: The island process
}

What makes an island? Scholars have been grappling with this question, even before islands have emerged as a distinct focus of academic inquiry. Islands have popularly and traditionally been associated with often rural, peripheral, and isolated landscapes and communities; and, in its efforts to counter or nuance these standardizing and generic tropes, island studies has tended to reinforce them through a selective focus on a particular type of island community (relatively rural, peripheral, and isolated) to the exclusion of island cities. 


\section{E. Pigou-Dennis \& A. Grydehøj}

Mirroring a similar movement in urban studies (e.g., Brenner, 2014), there has been a movement in island studies to regard islands less as places than as processes. Teaiwa (2007) suggests transforming 'island' from a noun to a verb; Baldacchino (2008, p. 44) notes "the richness of literary and cultural islanding;" and McCusker \& Soares (2011) speak of identities being 'islanded' through the reverberations of colonialism. Spatial islands begin as 'islands of the mind' (Gillis, 2004). For Baldacchino \& Clark (2013, p. 130),

Once an island is sought, it has already been discovered. There cannot not be an unknown island. Islands are caught in this vortex of being, becoming and much wishful, projected and programmatic thinking.

This is a variation of the old If a tree falls in the forest... conundrum: If a piece of land is surrounded by water, and no one wishes to be metaphorical, does it make an island?

The present paper explores this question by considering the history of island cities in Europe (for example, Amsterdam, Copenhagen, and Paris) and then focusing on the case of Belize City. Discussion of 'island cities' here is limited to densely urbanized small islands or urban archipelagos and does not include urban centres of larger islands or archipelagos (for example, Reykjavík and Port Vila). Similarly, bearing in mind that useful distinctions can be made between solitary islands on the one hand and archipelagos (groups of islands) on the other (Grydehøj \& Hayward, 2014), for the sake of simplicity, we here regard both densely urbanized solitary islands and archipelagos as 'island cities'.

If the concept of island cities itself represents a challenge to island studies, then the cases considered here compound the challenge, for Belize City and many of the European island cities are not self-evidently islands or archipelagos at all. In the case of Belize City, not only do bridges connect various parts of the city on the ground, but the city has the appearance of a peninsula from the map and from the air. These cities are not widely regarded as having island characteristics in either scholarship or the popular consciousness. However, from a narrow spatial perspective, these cities are (or in some cases, were) most certainly islands or archipelagos - though as we shall see, their conceptualizations and constructions as island cities took place in very different ways. This leads to the question: Who, ultimately, gets to decide whether a place is an island?

Belize City is particularly worthy of focus in this context precisely because it is so illusively clear that it is not an island. Belize as a whole (the sovereign state and former colony) is one of a few Caribbean microstates that is not an island state. Belize City is the urban centre of a mainland state rather than the urban centre of a larger island. By selecting a case like Belize City over more obvious Caribbean island examples, we can better understand the island process.

We argue that island spatial attributes and understandings of what it means to be an island strongly influence urban planning and development. We also argue that island cities may undergo processes of islanding, de-islanding, and re-islanding. Island status is linked to constellations of spatio-temporal factors, which ultimately result in a kind of 'sticky' historicity: time-specific cultural conceptions and physical constructions become stuck to particular sites, affecting the direction of future development. This paper is thus a study in island urban design. 'Design' here does not refer exclusively to the work of professional urban planners and architects but also includes the ordinary and informal activities of city inhabitants, 
who build and shape the urban environment through their actions. All cities - even 'unplanned' ones - are thus designed (Tonkiss, 2013).

The paper proceeds by considering: 1) the role of the ideal island city in European history; 2) Belize City's historical development; 3) future plans for Belize City's urban design; and 4) conclusions on the processes of islanding, de-islanding, and re-islanding.

\section{Ideal city, island city}

When it comes to islands, the much-discussed tropes of peripherality and isolation refer back, as scholars (Baldacchino, 2013; Jackson \& della Dora, 2009) have noted, to ideal islands: Plato's Atlantis, Euhemerus' Panachea, Sir Thomas More's Utopia, Sir Francis Bacon's Bensalem, and so on. Islands are, it turns out, ideal places on which to locate ideal communities. Their unambiguous borders mean that we can know precisely where they begin and end, and such fictional islands run to a large degree on the fiction of insular selfcontainment.

Yet, as Mumford (1965, p. 271) notes, utopias have also "largely been visualized in terms of the city." How can the island ideal of self-contained perfection be reconciled with the urban ideal? The answer lies in part with changing conceptions of the ideal city itself.

By the $17^{\text {th }}$ century, there had developed what amounted to a pan-Western European movement in urban design, driven by ideals of geometric order. The actual elements of geometrically informed ideal city planning were, however, much older. Grid plans had been used for urban development already in ancient Indus River and Huanghe towns (Yonekura, 2006). They had also developed in the Ancient Greek and Roman periods (Mazza, 2009; Evans, 2001, pp. 24-25) and preceded yet are associated with such early 'urban planners' as Hippodamus of Miletus (van der Vyver, 2013) and Vitruvius (Lagopoulos, 2009). In Medieval Europe, the grid plan was sometimes applied to new towns that needed to be constructed quickly. It was only in the European Renaissance though, that the concept of the ideal city per se once again rose to prominence, and from the mid-1400s, town planners - influenced by planners of military fortifications - began showing a philosophical preference for a perfect urban geometry focused on a definite central point. In practice, only few such Renaissance civilian ideal cities were actually built, with the Italian towns of Pienza and Palmanova being notable exceptions. The Baroque and then Rococo periods in the $17^{\text {th }}$ and $18^{\text {th }}$ centuries brought with them new philosophical ideas, which influenced the urban planning rubrics of the day. The open-air central squares of the Renaissance-era ideal city plans were now integrated into an orthogonal grid, which included central axes along which future expansion could take place (Rosenau, 2006; Eaton, 2002; Hall, 1997).

The grid could be a symbol of equality and egalitarianism, but it could equally be a symbol of centralizing power (Grant, 2011). From a planning perspective, such cities were designed to be sustainable: the Renaissance ideal of concentric rings was infinitely expandable, and the Baroque and Rococo ideal of main axes could be extended out into the very limits of the landscape. The grid system itself allowed for easy alteration and replacement of buildings and blocks within the larger urban context. For European urban planners of the time, coherence was its own virtue.

Yet the urban ideal of infinite expandability was in tension with a second urban ideal, namely that of the city's status as a bastion, exemplar, or oasis of self-contained perfection. It is no accident that both religious and secular Renaissance ideal city plans were inspired by 


\section{E. Pigou-Dennis \& A. Grydehøj}

military architecture, the epitome of self-containment. Defensive walls, battlements, and watercourses were reproduced in civic contexts, divested of practical - though not philosophical - military significance. A striking fictional example is Tomasso Campanella's City of the Sun, surrounded by seven concentric walls. As Stupar (2009, pp. 53, 57) notes, however, the concepts of "centralization and delimitation" are bound together in Renaissance urban planning philosophy by the ideal of finitude, "the paradigm of the geometrically perfect world which had to be planned, symmetrical and ordered around a focal point." In this mindset, the ability to project power is contingent upon the ability to clearly delineate the centre of this power.

Despite their diversity of philosophical perspectives, the various $15^{\text {th }}-18^{\text {th }}$ Century formulations of the European ideal city focused on how a city relates to its centre - on drawing civic activity in toward the centre while radiating influence from the centre out into the city's peripheries. A merging of the urges toward orderly grids and circular form resulted in an ideal of orderly, circular cities. Circular urban forms were desirable not only for purposes of military defence but also for how they represented the cosmos itself (Patricious, 1974). Palmanova is an example of this tendency. With construction initiated in 1593 by the Republic of Venice (which had previously transformed the ancient city of Nicosia, Cyprus into a star fort), Palmanova was built from scratch and thus ideal from the start.

Palmanova was, however, an exception, inasmuch as its planners did not need to work with an existing urban environment. This was not the case for those who sought to redesign major cities and thus needed to work with the material available. For instance, Amsterdam's $17^{\text {th }}$-century comprehensive re-engineering saw the five-fold replication of its original defensive moat into a series of concentric half-rings as well as a series of cross-canals. By multiplying Amsterdam's pre-existing islandness, this redevelopment turned the city into an intricate urban archipelago, with water weaving together a coherent urban fabric. Yet water not only connects; it also separates. Amsterdam's outermost canal belt was created to surround walled, bastioned fortifications. Prior to its late- $19^{\text {th }}$ century expansion, Amsterdam resembled a massive magnification of the fortress-island city of Naarden just upriver. Except that, whereas Naarden is stark in its insular singularity, Amsterdam is an archipelagic network of islands within canals within islands. The redesign of Amsterdam not only created islands; it also consolidated the mainland, with drainage projects removing the sea from the land (Hoeksema, 2007). Lest we are tempted to divest the human-made archipelago of Amsterdam of true island status, we may note that even Sir Thomas More's archetypal Utopia is an artificial island, separated from the mainland by a human-made channel (More, 2012, p. 84).

Amsterdam, as it turns out, is in good company. Most old European island cities - such as Bruges, Copenhagen, Paris, Stockholm, and Venice - were not comprehensively and professionally planned at the time of their inception, yet they all developed into major centres due to the establishment of seats of political and economic power on small islands, some of which had originally been created by relatively uncoordinated drainage engineering in earlier times (respectively, Abrahamse \& Kosian, 2013; Murray, 2005; Meisner, 2011; Jones, 2006; Stahre \& Wikström, 1986; Crouzet-Pavan, 2000). Such cities were later subject to intensive centrally managed urban planning that led to the creation of new land as well as re-engineered, elaborated upon, and rationalized existing waterways and canal networks within the existing cities. Paris, for instance, had its centre on the small Île de la Cité; but the construction of walls and ditches between the $12^{\text {th }}$ and $14^{\text {th }}$ centuries turned the whole of the city into a massive 
island intersected by the Seine. Over the following centuries, grand gates and bastions were added to the walls, which were integrated into the attempts to regularize the city's street plan.

A similar process took place in Copenhagen, a city centred on the small islands of Slotsholmen, which has served as Copenhagen's seat of political power since the $12^{\text {th }}$ century. In the early 1600s, Christian IV - Denmark's modernizing absolute monarch - changed the shape of the city by strengthening its fortifications and extending its lake perimeter on the large island of Zealand to the west, constructing a semicircle of artificial islands and ramparts between the city and the large island of Amager to the east, and beginning work on a moated citadel by the north harbour entrance (Green Therkelsen, 2012). The result was the creation of a fortified island encircling an urban archipelago.

The islandness of cities like Amsterdam, Paris, and Copenhagen is not incidental. Historically, forces of organized authority have selected small islands as sites on which to centre their power because small islands facilitate the maintenance of territoriality for purposes of trade with or political control over a wider area. That is, the ideal of the city (defended against incursion yet capable of projecting power out beyond the urban core) dovetails with the attributes of the small island (spatially distinct, easily defensible, and with access to waterborne transport). Where small islands did not exist from the start, they were often created: Brussels, Gdansk, Geneva, Groningen, Nicosia, Valletta, Vienna, and countless other European population centres were systematically walled and islanded in the Middle Ages and the Renaissance. Even where small islands already existed, as we have seen, further more-or-less circular islands were constructed around them. As Baldacchino (2005, p. 247) notes, although real islands do not tend to be particularly circular, ideal islands do.

For a period, then, the urban ideal and the island ideal coincided. Yet as a result of urban expansion and the declining power of the old planning philosophies, few if any of the old major small island cities of Europe are today regarded as island cities. Old borders have been outgrown, canals have been altered or filled in, fortifications have been levelled, and the cities have returned to, or become, part of the mainland. The demands of urban and state territoriality have changed (Sassen, 2006).

The European island cities considered above were either centred on islands or transformed into islands, and all underwent centrally led processes of conscious urban design to accentuate or create island attributes so as to better facilitate the exercise of economic and political power. They were also centres of power in themselves. In this, they differ from Belize City, the focus of the next sections of this paper. As we shall see, Belize City is very much an accidental island city: unplanned, ad hoc islanded, contemporary with the heyday of island city development yet separated from it. How has this difference affected Belize City's precise island status, and how is it related to the different intentions underlying Belize City's founding and continued development?

\section{Belize City: From swamp to islands to peninsula}

The spatial characteristics of Belize City today are very different than they were at the time of the city's establishment. Ever since its inception, Belize City has been a highly ambiguous space, embracing sea, river, wetlands, forest, islands, and mainland. This multifaceted spatiality has shaped the imprint of the emergent settlement, which has morphed from outpost to city. Unlike the European island cities, Belize City has only become a centre of economic and political power relatively recently. It is a colonial city rooted in the needs of British 


\section{E. Pigou-Dennis \& A. Grydehøj}

colonial power. In colonial cities, "infrastructure was often explicitly designed to support the extraction of resources from productive enclaves" and the transfer of these resources to the colonial power (Graham \& Marvin, 2001, p. 83).

Although Spain undertook colonial activity throughout Central America, present-day Belize was not a major site of Spanish urban activity, which focused on other parts of Central America (Rodriguez, 2005). The establishment of a British presence in what would eventually become Belize City belonged to a $17^{\text {th }}$-century British pattern of settlement in the archipelagic Leeward Islands and Jamaica, where colonial outposts demonstrated a capacity to act upon economic contingency and expediency (Havinden \& Meredith, 1996).

What is now Belize City began in the $17^{\text {th }}$ Century as two small settlements on the Caribbean Sea fringe of the Spanish colony of Honduras. These settlements initially consisted of encampments of buccaneers, who preyed on the Spanish territories, and later came to be bases for the logging industry. The first settlement, founded in mid-1600s, was situated on the tiny island of St George's Caye, $16 \mathrm{~km}$ offshore. In the late 1600s, St George's Caye became a home for loggers (Garber, Awe, \& Sullivan, 2010), and by 1764, the island had 17 settler houses, 'negro quarters', warehouses, a blacksmith's shop, provision grounds, two docks, a boatyard, turtle corrals, and gallows (Garber, 2009, p. 33) and was home to a medley of English, Scottish, and Mestizo settlers as well as African slaves who were primarily occupied with the felling of logwood and mahogany trees. The settlement followed the horseshoe-shaped coral island's curved northern coastal strip. At this stage, the island hosted no civic or public spaces (unless one counts the gallows): just the rudiments of shelter and activities related to ship maintenance and the provision of foodstuffs.

The caye was one site in a two-step staging post that facilitated the insinuation of European activity into the Central American tropical rainforest. In 1763, the Spanish granted the loggers formal rights for felling timber, but settlement and farming on the mainland were not permitted. A small settlement - the second site in this two-step staging post - was, however, established on a small island at the north mouth of Haulover Creek, in the Belize River delta. This settlement was Fort George (initially known as Fort Balcarres), and like so many similar fortifications elsewhere, its built defensive structures were augmented by the natural defensive attributes of an island location. Besides its military purpose, Fort George was the site of warehouses, docks, and mercantile establishments. Up until the peace treaty of 18141815, the colonial agenda in Belize consisted primarily of guarding Haulover Creek (which was a gateway to the logging industry upriver) and providing just enough logistical support to get by in terms of shipping and merchandising (Everitt, 1986).

The presence of British settlers on St George's Caye was intermittently threatened by Spanish raiders. In 1779, the Spanish raided St George's Caye, and some of its residents were captured and sent to Cuba while others relocated to land on the South Side of Haulover Creek. Spanish sources report that, at the time of the raid, St George's Caye had a population of 101 white people, between 200-250 slaves, and 40 people of mixed race (Bolland, 2003, p. 31). British-Spanish tensions culminated in the decisive Battle of St George's Caye in 1798, in which the British and their allies defeated a Spanish settler-militia. After this battle, St George's Caye no longer housed a considerable population, and settlement shifted to the areas at the mouth of Haulover Creek. From the 1790s through the 1830s, the various nodes of settlement in present-day Belize City gradually merged into a single town. The locations of these nodes of settlement - basically, low-lying river delta islands - proved challenging for human habitation. Land had to be reclaimed by draining wetlands and filling them in with 
materials such as felled mangrove, wood chips, bricks, coconut husks, coral, and sand (Everitt, 1969, pp. 57-61). Even after such work, this reclaimed land was below sea level and prone to flooding. Yet, in the end, the islands and wetlands at the mouth of Haulover Creek were consolidated into a single urban landscape. Life in colonial Belize during this period was at times fraught, with conflicts between European masters and African slaves as well as between rich and poor settlers at times erupting into violence (Bolland, 2003, pp. 17-49).

A key spatial factor for Belize City has been the fact that Haulover Creek bifurcates the city into two distinct regions: significantly, without a central island within the river (as was present in cities such as Nantes, Paris, and Strasbourg). If the North Side of Belize City must follow the coast, then the South Side is splintered by its waterways and cut off from the North Side. On the North Side, the street layout was curvilinear, following the curvature of the northeast coastline. On the later-constructed South Side, a more orderly grid ended up developing (Everitt, 1969, p. 77), but here too, the landscape foiled attempts to construct any kind of cohesive urban layout, even after the city had begun to host considerable administrative functions (Figure 1).

Figure 1: Map of Belize City, 1841. Note that the later-constructed South Side possesses a grid plan, in contrast to the earlier-constructed North Side. Fort George island remains far out at sea.

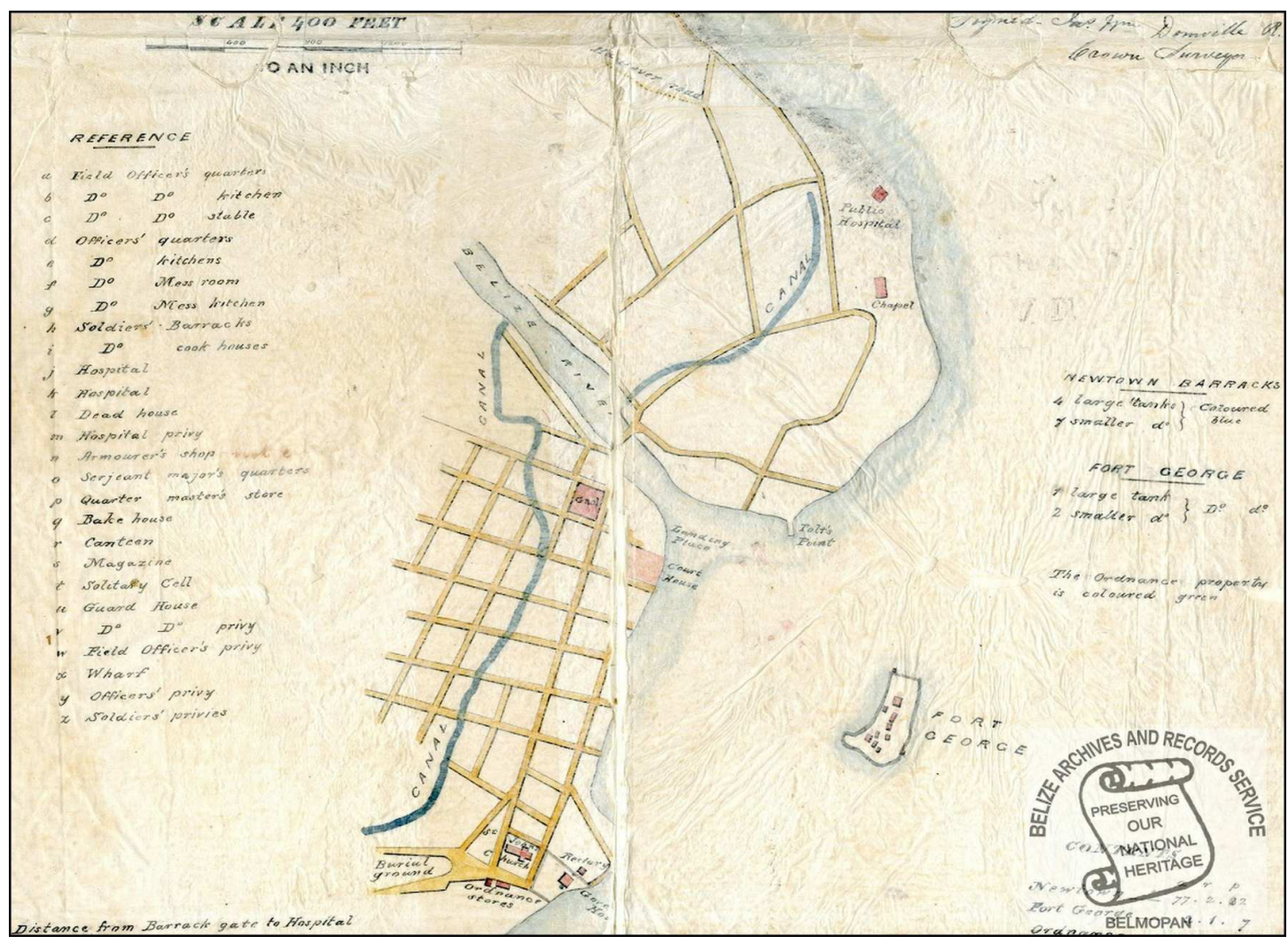

Source: Belize Archives \& Records. 


\section{E. Pigou-Dennis \& A. Grydehøj}

Up until the Great Depression, Belize City's development responded to the vagaries of the logwood and mahogany trades. The lumber industry was still the mainstay of the economy (Weaver \& Sabido, 1997), yet the region's geopolitical complexities and economic fluctuations created an unstable context for urban development. Problematic conditions included hostilities between Spain and the United Kingdom; conflicted relations between the United States and British colonies; the wars of independence on the part of Spain's American colonies; changes in demand for logwood; and an influx of settlers and slaves from Jamaica, the Eastern Caribbean, and the Honduran coast. Indeed, in 1790, the visiting Spanish official Rafael Llobet commented that emerging city to the north and south of Haulover Creek lacked squares, streets, order, and symmetry as well as that its collection of 138 houses lacked visual coherence (Mayr, 2014, p. 160). Thus, from the Spanish colonial perspective, the settlement seemed unplanned. Nevertheless, crucial additions to the urban fabric took place in the following decades, including the construction of St John's Anglican Cathedral (1812), the Governor's residence, barracks, a market, and a slaughterhouse (1820) as well as piecemeal land reclamation for new building lots, roads, and canals. Bridges played a significant role in this city divided by water. The oldest existing bridge, at the mouth of the Haulover Creek, is the Swing Bridge (1923), which connects Queen Street on the North Side to Albert Street on the South Side.

In 1862, the settlement in Belize was officially recognised by the United Kingdom as the colony of British Honduras, and in 1865, Belize's major town gained official city status as Belize City. British Honduras gained independence as the sovereign state of Belize in 1981.

Over time, urban growth fuelled further ambitions for re-engineering the landscape and seascape. Land was reclaimed on the South Side to create the Foreshore, Queen's Square, and Queen Charlotte Square. In the 1880s, land was reclaimed on the North Side to join the historic island outpost of Fort George with the 'mainland', as well as to create the districts of Cinderella Town, King's Park, and Caribbean Shores.

Nevertheless, bounded by the sea to the north, south, and east, Belize City also expanded to the west through inland land reclamation (World Bank, 1993, p. 2). Because much of the city lies at or below sea level, it was necessary to build canals to drain the land and channel floodwaters out to sea. The completion of the north-south Collet Canal (1919) and Burdon Canal (1929) improved both drainage and accessibility (Macpherson, 2007, pp. 104105; Everitt, 1969, p. 55). The major canals created an east-west bifurcation of the city, effectively resulting in an urban space divided into quadrants - and eventually even smaller sections - that were bounded by water on two or more sides. As in Belize City's past, not all land reclamation is centrally administered, and squatter communities have sprung up on illegally reclaimed land (Inter-American Development Bank, 2011a, p. 12). Through this process, the construction of canals and filling in of wetlands transformed the river delta of Haulover Creek into a peninsula - or perhaps more accurately, an urban archipelago, a collection of (relatively) dry islands where unstable wetlands once had been (Figure 2). 
Figure 2: Stages of land reclamation from mangrove forest in Belize City. Mangroves (grey) are cleared and land is built as settlement spreads west along the peninsula. Panels from left: 1) $1800 \mathrm{~s}, 2)$ mid-1900s, 3) early $21^{\text {st }}$ century.

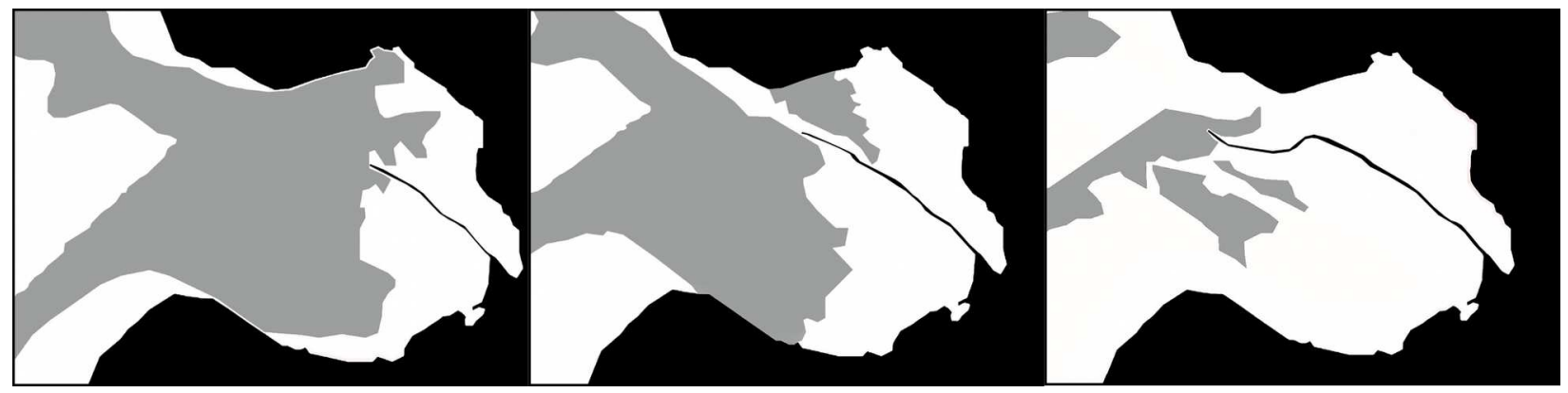

Source: Ricketts, Spooner \& Neil (2014). All rights reserved. Reproduced with permission.

One north-south canal (present-day Canal Street and the North Side Canal between Queen Street and Hyde Lane) stretches from the Caribbean to the Caribbean, while numerous other waterways (for instance, the Partridge Street-North Creek-Collet Canal complex) split the South Side into numerous segments. Even today, during high tide and heavy rainfall, the creeks and canals overflow, and floodwaters run into the city streets, temporarily islanding sections of the city. The various stages of land reclamation within the city, with contiguous plots of land being drained in different periods, resulted in mixed and "hap-hazard" (Everitt, 1969, p. 79) development as well as micro-zonal differentiation in use and architecture. Land reclamation around the city centre continues, so that, for example, a new piece of land was reclaimed above Fort George on the North Side in the 2000s (Figure 3).

Figure 3: Reclaimed land (orange) to the north of Fort George, constructed in the 2000s.

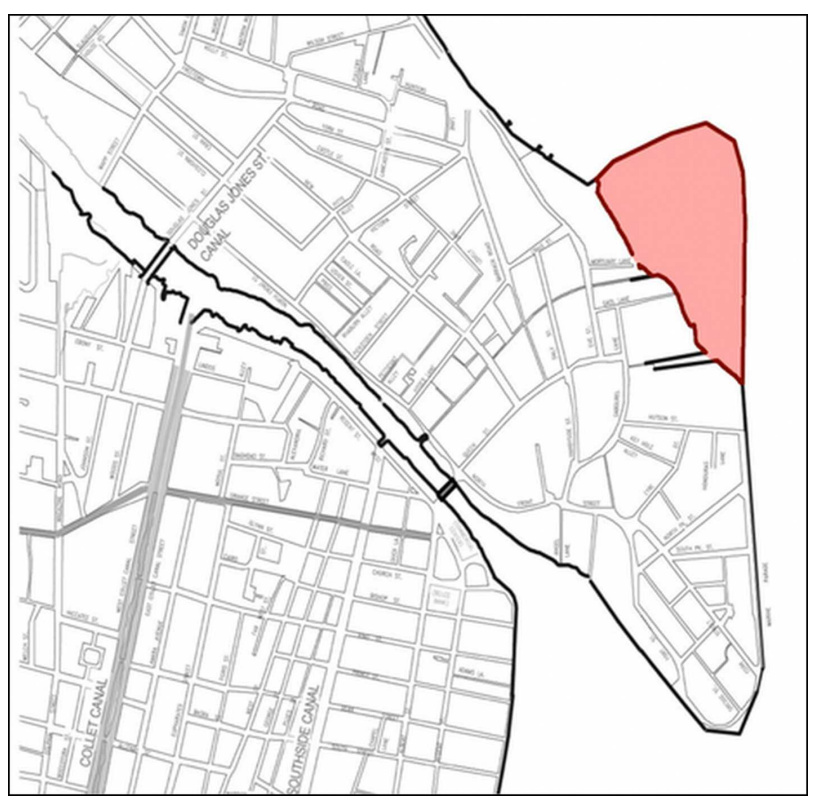

Source: Ricketts, Spooner \& Neil (2014). All rights reserved. Reproduced with permission. 


\section{E. Pigou-Dennis \& A. Grydehøj}

As the colony's - and later, country's - chief port and commercial centre, Belize City came to host significant economic activity, even though this was of a somewhat desultory nature. The city's population increased from 6,000 in 1859 to 39,887 in 1986 (Everitt, 1986) to around 70,000 in 2014. This is despite the fact that, following the devastation wrought by Hurricane Hattie in 1961, the capital of Belize was shifted to the new, planned city of Belmopan.

Although its history began on a small island (or rather, two small islands), as was the case with many European island cities, and although it was founded in the European heyday of systematic urban islanding, Belize City's development did not follow typical contemporary European patterns of urban design on islands. Belize City did not become a round island or encircled urban archipelago. Given the difficult spatial aspects of its river delta location, the planned development of Belize City into a true urban centre would have required a massive initial investment in land reclamation, drainage, and canal construction. Yet British Honduras and, by extension, Belize City were not subject to intense British colonial interest. The city served the needs of British political authority without being significantly under the control of this central authority. It was, after all, only in 1862 that British Honduras as a whole was proclaimed a British colony. In 1934, Aldous Huxley (1984, p. 21) drily remarked that "If the world had any ends, British Honduras would certainly be one of them. It is not on the way from anywhere to anywhere else." Though very much a European colonial city founded on European colonial needs, Belize City lacked strong administrative connections to its colonial power. It was not designed as a bastion of authority. In fact, it was not designed at all.

Because of these historical and spatial conditions, Belize City was never intensively engineered or re-engineered by a central authority. Instead, canals were constructed and new land was built according to the needs of its residents and businesses on an ad hoc basis. This was not, perhaps, particularly unusual for cities in general, where major urban development projects have often been undertaken by actors outside of the formal political system, but it was unusual for European and European colonial densely urbanized small islands during this period. As a result, despite being very much an island, then an archipelagic, city during its early development, it today possesses few obvious island spatial attributes. The city instead has the appearance of a peninsula split by a river.

\section{Islanding by design}

The European ideal city and the European ideal island were, as we have seen, closely related. Yet, as today's dominant trope of the rural, peripheral, and isolated island suggests, the island and the city have since suffered a conceptual separation. Amsterdam, Paris, Copenhagen, and so on are now very rarely regarded as 'island cities', even if they maintain island spatial characteristics. Perhaps this is directly related to their expansion beyond former island borders. It could also be that the very ubiquity of island cities in Europe during this Middle Ages and the Renaissance, as well as the subsequent decline in the currency of ideal city philosophies, emptied the concept of the island city of distinctive meaning. The ideal island cities are no more; not necessarily because they no longer exist but because people no longer have a need for them. Yet, islandness has an abiding effect on urban planning, development, and design in Europe's old island cities. The canals of Amsterdam continue to inflect the city's character; the various merged and artificial islands of the Copenhagen archipelago continue to develop in shape and use; and Paris continues to centre on its island core while its ring roads follow the 
old aquatic boundaries. These cities possess a 'sticky' historicity: an island once made is difficult to completely undo.

What of Belize City? Belize City was never an ideal city or an ideal island. Due to its river delta location, proximity to mangrove wetlands, piecemeal land reclamation schemes, and lack of focused urban planning, it developed with neither a clear centre nor dominant axes, outside the confines of European urban geometry of the period. It is a city by accident, beginning as a staging post on a tiny caye, with the sole purpose of extracting and shipping inland forestry products. The forestry endeavours proved sufficiently successful to enable more expansive settlement, yet spatial attributes and the absence of an original urban objective colluded to result in a messy process of urban creation, built from a questionable bedrock of swamp, water, and a handful of sandy islands.

In time, land triumphed over water. Land reclamation from the sea to the east and from wetlands to the north, south, and west captured terrain that was habitable in the dry season and that more or less endured - with the assistance of stilts and boats - in the wet season. The Fort George island eventually joined the mainland through the building up and reclaiming of land from the sea and river mouth. The Foreshore on the South Side was likewise created, and swamp reclamation allowed the westward expansion of housing developments.

Today, at first glance, Belize City hardly seems an island city at all. Many of its canals have been covered, the primary routes inland are now by road rather than by river, and land reclamation has consumed much of the city's natural islandness. Even Fort George is no longer self-evidently an island. As if to cast Belize City's mainland status into sad relief, the region's major tourist attractions are Caye Caulker and Ambergris Caye, offshore islands that sell an archetypal Caribbean island sun, sea, and sand tourist experience.

Yet, Belize City's river delta archipelagic past still plays a role. This is not merely an immediate result of changes to the landscape (from wetlands to islands to peninsula). It is also a result of how these temporally specific landscape changes influenced the urban development process. By the time the wetlands had been filled in and the city made whole, the 'damage', in a sense, had already been done, and the city possessed neighbourhoods of diverse and 'sticky' historicity, neighbourhoods that were driven by the echoes of their past spatial and socioeconomic conditions. Roads atop the canals have reproduced the old waterborne transport routes. Flooding periodically returns the city to its former archipelagic state. Lack of land to the north, south, and east pushes urbanization westward. Urban development is cumulative, and new designs are built upon the old. So, from a developmental perspective, it can be argued that Belize City will never cease to be an island city. Even if all traces of the original river delta are erased, the city's historical islandness will continue to echo in its future development.

Such echoes can at times resound louder than others. A government-led 20-year Master Plan (Belize City Council, 2014) has set out to improve living conditions in Belize City. Planned improvements to the canal infrastructure are designed not only to reduce flooding (Inter-American Development Bank, 2011b) but also to return the city's waterways particularly Collet Canal and Haulover Creek - to the centre of its urban life. The Master Plan notes that Belize City's spatial situation has led to a "lateral" growth pattern in which expanding suburbs "along two thin strips" to the northwest and southwest remain dependent on services provided by a city centre located at the extremity of a peninsula, thereby limiting opportunities for further urban expansion and resulting in an under-exploitation of "the economic advantages of the spatial concentration of urban functions" (Betancourth, 2011, pp. 9, 14). In light of these spatial problems, the Master Plan calls for: 


\section{E. Pigou-Dennis \& A. Grydehøj}

... development to take place around a central core of rehabilitated water bodies (canals, creek, river and coastal front), and of rehabilitated and conserved landscapes, mangrove forests and wetlands. It also concentrates economic activities and increases population densities within the current city administrative boundaries. An important area within this scenario will be located on the historical Belize river course (including the creek and the channels), which will be planned for a variety of uses, including commercial, cultural and recreational uses (Betancourth, 2011, p. 18).

Faced with the difficult spatialities of present-day Belize City (which differ from those of the past), the Master Plan embraces the city's inherited and variegated developmental histories by supporting a combination of waterfront revitalization, urban densification, zonal differentiation, and the creation of clearly delineated satellite communities. This represents an attempt to wrest control over unplanned 'splintering urbanism' (Graham \& Marvin, 2001), though it is less an attempt to make the city more cohesive than to make the city fragmented in a planned manner. It is part of a worldwide trend toward urban renewal mega-projects of zonal specialization, which can involve a tension between serving the collective interest (through spatially differentiated division of urban services) while "simultaneously re-inscribing and reinforcing socioeconomic divisions" in the city (Lehrer \& Laidley, 2008).

Beyond its immediately practical focus, the Master Plan also engages in a kind of spatial heritage, a harkening back to the city's rootedness in its landscape:

Belize City is a delta, lowlands, and riverine flood plains water city. It is a river city, composed of historic liquid landscapes and aquatic areas, located in a flood-prone delta area at the confluence of the Belize River and the Caribbean Sea. This historical character of the city, its water landscapes, and its relative compactness are the specific qualities of the city that may give it a unique identity though which is not yet fully identified and recognized by its citizens. The water in and around the city is one of the qualities that distinguishes Belize City from most other cities. The awareness that this is a huge asset for the city will only grow stronger. These unique assets constitute its unique strengths, potentials and opportunities (Betancourth, 2011, p. 33).

Betancourth and Morató (2014) elsewhere describe this process as one of "remaking the resilient urban archipelago" and stress not only the country of Belize's formal status as a Small Island Developing State but also Belize City's status as a city of islands (see Figure 4).

Canal and waterfront revitalization is a common element of urban renewal projects in general and in island cities in particular (e.g., Chang \& Huang, 2011; Dodman, 2007; Desfor \& Jørgensen, 2004; Hoyle, 2002). The Master Plan further seeks to draw upon the city's spatiotemporal context and undertake what amounts to heritage production: explicitly without the cultural recognition of the city's current population. Such top-down heritagization is not unusual and can sometimes be successful, at least within its own more or less narrow framework (Ronström, 2008), though it can also enter into a losing conflict with local cultural conceptions (Grydehøj \& Hayward, 2011; Grydehøj, 2011). In the event that the Master Plan should come to fruition, it will be interesting to see whether it has proved possible not only to instil in residents a sense of the city's uniqueness but also to recreate a sense of a lost riverine 
identity. If the canals are restored and moved to the centre of urban life, they may have the effect of partially re-establishing the city's status as an urban archipelago.

\section{Figure 4: Islands of Belize City today.}

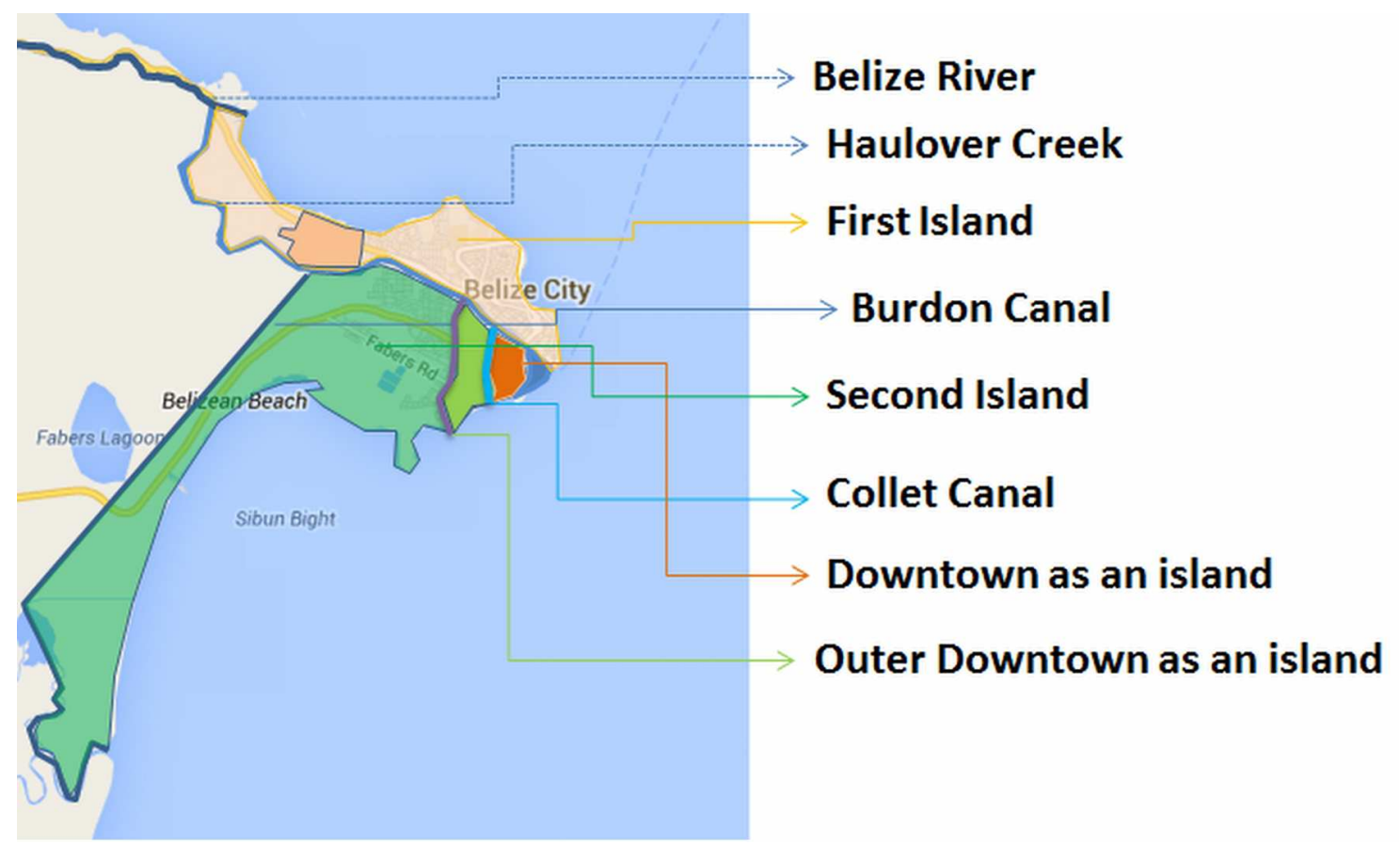

Source: C.H. Betancourth. All rights reserved. Reproduced with permission.

\section{Conclusion: Islanding, de-islanding, re-islanding}

Comparing developing European ideals of the island and the city and how these were deployed in Europe itself with the history of Belize City illustrates that 'the island city' is not just one thing. Unlike the abstracted ideal island city, 'real' island cities are complex and individual. Belize City represents just one story of urban island development. It is a vanished archipelago, an archipelago in the making, a disordered example of island urban design. In contrast, the old European island cities were re-designed in a relatively orderly fashion in the Renaissance period, and their islandness was often multiplied to turn the city as a whole into a large circular island containing numerous smaller islands. Yet whatever the intentions of their professional designers, the idealized plans for the old European island cities did not result in standardized cities. Local spatial, cultural, political, architectural, military, and economic conditions influenced the final results: The contemporaneous re-engineering and multiple islanding of Amsterdam and Copenhagen did not create identical island cities. In the words of Tonkiss (2013, p. 6), "the map, or the plan, is never the same as the territory."

Arguing against the deductive use of rural small islands in research and representation, Ronström (2013, p. 2) asks, "Does it really matter which island you choose to study, when you in any case will end up dealing with just about any island?" The same criticism can be levelled at attempts to view all island cities as the same or - just as bad - to starkly and artificially 


\section{E. Pigou-Dennis \& A. Grydeh $\phi j$}

differentiate between the island and the city. To do so is to favour one island ideal over other island ideals and other island realities.

But is this, perhaps, itself too artificial an approach? Does it go too far in taking in 'the big picture' at the expense of individual experience? If a tree falls in the forest, and we can only 'hear' it because we have taken to periodically measuring forest density by satellite, does it really make a sound? If some island studies scholars wish to make islands out of every piece of land surrounded (or formerly surrounded) by water, does that really produce islands? Does an island exist if the people who live on it do not deem it to be an island?

This a relevant question for the old European cities that were designed as islands or archipelagos at various points in their history but have ceased to be regarded as such. To call these places island cities might appear to privilege the visions of planners, philosophers, kings and queens. Yet such islandness was not simply designed by a handful of decision-makers; it was constructed, put into practice, and maintained over the course of centuries by many thousands of city residents as well. The question is perhaps even more relevant to a place like Belize City, which was never a comprehensively designed island city. Nevertheless, its islandness and its citiness were produced by the actions of countless individual business, state, and private actors who created, fractured, and merged the land on which the city was built. Like the old European island cities, Belize City has been de-islanded in the public consciousness.

Yet, if a city can be islanded and de-islanded, can it not be re-islanded too? Our willingness to regard More's fictional Utopia and Dubai's attempted engineering of island paradises as 'true' islands suggests that, given sufficient will, human-made islands can be created from scratch. The key here is less the spatial attribute of islandness itself than the will to apply it. The planners who are working to reshape Belize City possess such a will, and if they succeed through waterfront revitilization in convincing residents, makers of 'ordinary urbanism' (Tonkiss, 2013), that theirs is indeed a city of islands, then islands will indeed have been made. Mental islands will have been revived after a long spatial absence. Nor is Belize City an exceptional case in this regard. For instance, the local organizers of the Eurovision Song Contest held in Copenhagen in May 2014 rebranded Refshaleøen (a largely artificial island in Copenhagen harbour, constructed in the 1600-1800s) as 'Eurovision Island': Even though the Danish word for 'island' ( $\varnothing e n)$ had always been present in its Danish name, this English-language renaming produced amongst Copenhageners a renewed recognition of the site as an urbanized island (Koefoed, 2014).

To enquire as to why people may be driven to re-island a piece of mental mainland is a task too great for the present paper. Suffice it to say that the mysterious 'island lure' (Baldacchino, 2012) has proved powerful in the past. The search for a greater understanding of the islanding process - of how islands are created, destroyed, and reimagined in our minds encourages us to explore the full range of islands throughout history, not just the contested utopias of today. 


\section{References}

Abrahamse, J.E., \& Kosian, M. (2013). A metropolitan countryside: Peatland reclamation and the birth of a world city. Landscapes, 14(2), 117-140.

Altshuler, A.A., \& Luberoff, D. (2003). Mega-Projects: The Changing Politics of Urban Public Investment. Washington, DC: Brookings Institution Press.

Baldacchino, G. (2013). Only ten: Islands as uncomfortable fragmented polities. In G. Baldacchino (Ed.), The political economy of divided islands: Unified geographies, multiple polities (pp. 1-17). Basingstoke: Palgrave Macmillan.

Baldacchino, G. (2012). The lure of the island: A spatial analysis of power relations. Journal of Marine and Island Cultures, 1(2), 55-62.

Baldacchino, G. (2008). Studying islands: on whose terms? Some epistemological and methodological challenges to the pursuit of island studies. Island Studies Journal, 3(1), 37-56.

Baldacchino, G., \& Clark, E. (2013). Guest editorial introduction: Islanding cultural geographies. Cultural Geographies, 20(2), 129-134.

Belize City Council. (2014). Master Plan Documents. Retrieved from http://www.belizecitycouncil.org/Master_Plan_Documents

Betancourth, C.H., \& Morató, J. (2014). Multifunctional eco-infrastructures for remaking the resilient urban archipelago: The case of Belize City. Abstract for presentation at Island Cities and Urban Archipelagos, Copenhagen, October 2014.

Betancourth, C.H. (2011). Urban development scenarios for Belize City 2010-2030: Recommended scenario, evaluation of national infrastructure plans and key investment projects, Annex 1. Belize City: Government of Belize, Inter-American Development Bank, \& Belize City Council.

Bolland, O.N. (2003) Colonialism and resistance in Belize: Essays in historical sociology. Belize et al:: Cubola Productions \& University of the West Indies Press.

Chang, T.C., \& Huang, S. (2011). Reclaiming the city: waterfront development in Singapore. Urban Studies, 48(10), 2085-2100.

Crouzet-Pavan, E. (2000). Toward an ecological understanding of the myth of Venice. In J.J. Martin \& D. Romano (Eds.), Venice reconsidered: The history and civilization of an Italian city-state, 1297-1797 (pp. 39-64). Baltimore MD: John Hopkins University Press.

Desfor, G., \& Jørgensen, J. (2004). Flexible urban governance: the case of Copenhagen's recent waterfront development. European Planning Studies, 12(4), 479-496.

Dodman, D. (2007). Post-independence optimism and the legacy of waterfront redevelopment in Kingston, Jamaica. Cities, 24(4), 273-284.

Eaton, R. (2002). Ideal Cities: Utopianism and the (Un)built Environment. London: Thames \& Hudson.

Evans, G. (2002). Cultural planning: An urban renaissance?. London: Routledge.

Everitt, J.C. (1969). Terra Incognita: An analysis of a geographical anachronism and an historical accident; or Aspects of the cultural geography of British Honduras C.A. Master's thesis, Simon Fraser University. 


\section{E. Pigou-Dennis \& A. Grydeh $\phi j$}

Everitt, J.C. (1986). The growth and development of Belize City. Belizean Studies, 14(1), 75111.

Garber, J.F. (Ed.) (2009). The St. George's Caye Archaeology Project: Results of the 2009 field season. Belmopan: National Institute of Culture and History.

Garber, J.F., Awe, J.J., \& Sullivan, L.A. (2010). In J. Morris, S. Jones, J. Awe, G. Thompson, \& M. Badillo (Eds.), Research reports in Belizean archaeology, 7, 259-266. Belmopan: National Institute of Culture and History.

Gillis, J.R. (2004). Islands of the mind: How the human imagination created the Atlantic World. London: Palgrave Macmillan.

Graham, S. \& Marvin, S. (2001). Splintering urbanism: Networked infrastructures, technological mobilities and the urban condition. New York: Routledge.

Grant, J. (2001). The dark side of the grid: power and urban design. Planning Perspectives, 16(3), 219-241.

Green Therkelsen, K. (2012). Kфbenhavns Museum arkaologisk rapport 2012: KBM 3928 Vester Voldgade m.fl. - Vestervold Kvarter, Kфbenhavns Sogn, Sokkelund Herred, Kobenhavns Amt. Copenhagen: Museum of Copenhagen.

Grydehøj, A. (2011). 'It's a funny thing that they were all bad men': cultural conflict and integrated tourism policy in Shetland, UK. International Journal of Tourism Anthropology, 1(2), 125-140.

Grydehøj, A., \& Hayward, P. (2014). Social and economic effects of spatial distribution in island communities: comparing the Isles of Scilly and Isle of Wight, UK. Journal of Marine and Island Cultures, 3(1), 9-19.

Grydehøj, A., \& Hayward, P. (2011). Autonomy initiatives and quintessential Englishness on the Isle of Wight. Island Studies Journal, 6(2), 179-202.

Hall, T. (1997). Planning Europe's capital cities: Aspects of Nineteenth-Century urban development. London: Spon.

Havinden, M., \& Meredith, D. (Eds.) (1996). Colonialism and development: Britain and its tropical colonies, 1850-1960. London: Routledge.

Hoeksema, R.J. (2007). Three stages in the history of land reclamation in the Netherlands. Irrigation and Drainage, 56(1), 113-126.

Hoyle, B. (2002). Urban waterfront revitalization in developing countries: the example of Zanzibar's Stone Town. The Geographical Journal, 168(2), 141-162.

Huxley, A. (1984). Beyond the Mexique Bay. London: Triad.

Inter-American Development Bank (2011a). Issue Paper 07 - Existing Issues of the Environment in Belize City. Belize City: Belize City Council.

Inter-American Development Bank (2011b). IDB approves \$10 million loan to reduce flooding in Belize City. 9 September. Retrieved from http://www.iadb.org/en/news/newsreleases/2011-09-09/flood-mitigation-infrastructure-program-for-belize-city,9533.html.

Jackson, M., \& della Dora, V. (2009). "Dreams so big only the sea can hold them": man-made islands as anxious spaces, cultural icons, and travelling visions. Environment and Planning. A, 41(9), 2086-2104.

Jones, C. (2006). Paris: The biography of a city. London: Penguin. 
Koefoed, E. (2014). Værfts- $\varnothing$ bobbet op til pop. Magasinet KBH, 01 May. Retrieved from http://www.magasinetkbh.dk/indhold/refshale\%C3\%B8en-eurovision

Lagopoulos, A.P. (2009). The semiotics of the Vitruvian city. Semiotica, 175, 193-251.

Lehrer, U., \& Laidley, J. (2008). Old mega-projects newly packaged? Waterfront redevelopment in Toronto. International Journal of Urban and Regional Research, 32(4), 786-803.

Macpherson, A.S. (2007). From colony to nation: Women activists and the gendering of politics in Belize, 1912-1982. Lincoln, NE: University of Nebraska Press.

Mayr, R.J. (2014). Belize: Tracking the path of its history. Zürich \& Berlin: LIT Verlag.

Mazza, L. (2009). Centenary paper: Plan and constitution - Aristotle's Hippodamus: towards an 'ostensive' definition of spatial planning. Town Planning Review, 80(2), 113-141.

McCusker, M., \& Soares, A. (Eds.) (2011). Islanded identities: Constructions of postcolonial cultural insularity. Amsterdam: Rodopi.

Meisner, A. (2011). Slotsholmen - Hvilken ф?: Nye oplevelsesrum i Kфbenhavns historiske centrum. Masters' thesis, Roskilde University.

More, T. (1516/2012). Utopia. S. Duncombe (Ed.). Brooklyn NY: Minor Compositions.

Mumford, L. (1965). Utopia, the city and the machine. Daedalus, 94(2), 271-292.

Patricios, N.N. (1974). The conceptual determinants of two archetypal city forms. Journal of Environmental Planning and Management, 15(1-2), 4-17.

Ricketts, C., Spooner, M., \& Neil, J. (2014). Drawings resulting from Architectural Study Tour of Belize City, led by J. Lawton \& E. Pigou-Dennis. Kingston, Jamaica: Caribbean School of Architecture.

Rodriquez, R. (2005). The foundational process of cities in Spanish America: the Law of Indies as a planning tool for urbanization in early colonial towns in Venezuela. Focus, 2, 4758.

Ronström, O. (2013). Finding their place: islands as locus and focus. Cultural Geographies, 20(2), 153-165.

Ronström, O. (2008). A different land: heritage production in the island of Gotland. Shima, 2(2), 1-18.

Rosenau, H. (2007). The ideal city: Its architectural evolution in Europe. Abingdon: Routledge.

Sassen, S. (2006). Territory, authority, rights: From medieval to global assemblages. Princeton NJ: Princeton University Press.

Stahre, N.G., \& Wikström, J. (1986). Ortnamn i Stockholms skärgård. Stockholm: Max Ström.

Stupar, A. (2009). Urbs et orbis: (Re)charting the center, (re)positioning the limits. Spatium, $20,53-59$.

Teaiwa, T. (2007). To island. In G. Baldacchino (Ed.), A world of islands: An island studies reader (p. 514). Charlottetown, Canada, \& Luqa, Malta: Institute of Island Studies, University of Prince Edward Island \& Agenda Academic.

Tonkiss, F. (2013). Cities by design: The social life of urban form. Cambridge: Polity Press.

van der Vyver, Y. (2013). The Agora of Asia Minor: The shaping of the non-material by the material in urban space. South African Journal of Art History, 28(2), 275-293.

Weaver, P.L., \& Sabido, O.A. (1997). Mahogany in Belize: A historical perspective. Rio Piedras: International Institute of Tropical Forestry. 
World Bank (1993). Belize: Belize City infrastructure project. Washington DC: World Bank. Retrieved from http://documents.worldbank.org/curated/en/1993/11/698764/belizebelize-city-infrastructure-project

Yonekura, J. (2006). Indus towns and Huanghe towns: the origin of the grid pattern town plan. In R.B. Singh (Ed.), Sustainable urban development (pp. 402-415). New Delhi, India: Concept Publishing. 